\title{
DETERMINATION OF THE CONDITIONS FOR CARBON MATERIALS OXIDATION WITH CARBON MONOXIDE FORMATION AT HIGH TEMPERATURES
}

\author{
Yevgen Panov', Nikolai Gomelia1, Olena Ivanenko ${ }^{1,}$, Andrii Vahin ${ }^{2}$, \\ Serhii Leleka ${ }^{1}$
}

https://doi.org/10.23939/chcht14.04.545

\begin{abstract}
In this paper, the influence of carbon material type, temperature and oxygen concentration in gas mixture on the processes of carbon monoxide formation in production of the electrodes by graphitization was explored experimentally. Specific quantity of gas formed for a definite time, reduced to mass unit of carbon loading using pitch, packing materials and charge mixture of industrial use, was calculated. It is demonstrated that pitch provides the highest rate of carbon oxidation with the release of $\mathrm{CO}$ and substantially exceeds packing materials and charge mixture for this index.
\end{abstract}

Keywords: carbon monoxide, gas release, packing materials, pitch, charge mixture.

\section{Introduction}

Operation of a modern industrial enterprise should be in accordance with the principles of sustainable development, which, in turn, is guided by compliance with requirements of environmental protection, in particular, the control of emission of flue gases. At present, 'Ukrgrafite', PrJSC, that ranks high in the domestic industry as a supplier of electrode products not only for Ukrainian industry but for foreign consumers too, pays considerable attention to the issue of reducing the technological impact on the environment [1].

For decades, the Company has been systematically monitoring composition of the flue gases, the main harmful pollutant whereof is carbon monoxide (CO) [2]. The problem of formation of significant amounts of $\mathrm{CO}$ especially rises from the process of baking graphite "green" blanks in furnaces, which are heated to

\footnotetext{
${ }^{1}$ National Technical University of Ukraine "Igor Sikorsky Kyiv Polytechnic Institute",

37, Peremohy Ave., 03056 Kyiv, Ukraine

${ }^{2}$ Private JSC "Ukrainian Graphite",

20, Severnoye Shosse, 69600 Zaporozhye, Ukraine

olenka.vasaynovich@gmail.com

(C) Panov Y., Gomelia N., Ivanenko O., Vahin A., Leleka S., 2020
}

temperatures close to $1273 \mathrm{~K}$, according to a specified schedule and baking rate to ensure the required quality of the electrode products. Thus, the need to convert this process into an environmentally friendly component of the electrode production requires the search for effective solutions to reduce the $\mathrm{CO}$ formation in the process of electrodes baking. Among the proposed steps to reduce the intensity of gas release during baking the blanks, the determinative is modernization of the baking regulations [3], use of heat exchanger-utilizer for the local finish burning of $\mathrm{CO}$ [4], substitution of Riedhammer multichamber ring furnaces for tunnel baking furnaces [5], use of catalytic methods of decontamination of $\mathrm{CO}[6,7]$, etc. The introduction of these technical solutions at the enterprise is limited or impossible at all due to significant capital investments in the re-equipment of the production. Therefore, the solution of this issue in an economically feasible way without deterioration in the products quality is still important today.

As the study of gas release from the furnaces baking electrodes has shown [8], $\mathrm{CO}$ in the flue gases is formed both by the partial oxidation of the packing materials and materials of the charge mixture, as well as by the pitch degassing in the blanks. At the same time, the maximum concentration of carbon monoxide, measured directly in the chamber of the baking furnace, reached $3600 \mathrm{mg} / \mathrm{dm}^{3}$. It should be also noted that according to the results of previous studies, a sharp increase in $\mathrm{CO}$ concentration in flue gases occurs at the temperature of the blanks of $593-663 \mathrm{~K}$. The CO concentration achieved in the gas mixture remains practically unchanged until emission to atmosphere. Considering that the flue gases contain oxygen at concentration of $14 \%$ and water vapour at the concentration of $8 \%$, high $\mathrm{CO}$ content can be theoretically justified by the presence of a limiting stage of the carbon monoxide conversion into carbon dioxide. Generally, based on a slight increase in the rate constants of $\mathrm{CO}$ oxidation reactions for temperature, it was assumed that there is need of using catalysts for accelerating the oxidation processes. However, the use of a catalyst 
requires a clear knowledge of the source of $\mathrm{CO}$ formation, which in this case is limited to the general data of measuring its contents under the roof of the baking furnace chambers. Thus, there is a need to study the dependence of the amount of carbon monoxide formed on the type of carbon material used in the production of electrodes and conditions of their baking. But there is no clear data on the dependence of $\mathrm{CO}$ formation rates on temperature and oxygen concentration at baking the electrodes for now.

The objective of this paper is to study the processes of formation of carbon monoxide using such types of carbon material as packing materials, pitch and charge mixture for production of electrodes, depending on the temperature regime and content of oxygen in the gas mixture, by laboratory simulation of the processes of a multi-chamber baking furnace. A prerequisite condition for the simulation process is compliance with the thermal regulations of the furnace.

\section{Experimental}

Materials used for the study were thermo-anthracite packing materials, $2.8-6 \mathrm{~mm}$ of fineness, granular pitch, grade $\mathrm{B} 1$, and charge mixture for production of the electrodes, consisting of the components presented in Table 1.

Table 1

Charge mixture formula for the electrodes manufacturing

\begin{tabular}{|c|c|c|c|c|c|}
\hline Material & \multicolumn{3}{|c|}{ Electrically calcined anthracite } & \multicolumn{2}{c|}{ Graphite cuttings } \\
\hline Granulometry & $6-28$ & $28-1$ & Fine powder & $6-1$ & $1-0$ \\
\hline$\%$ & 23 & 17 & 30 & 12 & 18 \\
\hline
\end{tabular}

For simulation of gas release processes in a baking furnace a laboratory facility was created, the layout whereof is shown in Fig. 1. It includes: thermal chamber $\mathbf{2}$, consisting of ceramic tube $\mathbf{5}$ with heating element $\mathbf{6}$, which maintains preset temperature level. A sample of carbon material was placed in the thermal chamber (packing materials, pitch and charge mixture). The charge mixture and packing materials were kept in a cage of stainless steel mesh. Pitch was placed in a ceramic crucible. Temperature controller $\mathbf{3}$ connected to thermocouple $\mathbf{4}$ controlled the preset temperature level. The temperature was changed from room temperature to $1123 \mathrm{~K}$ discretely at different rates of the temperature rise [9]. Gas release was controlled by the change in the concentration of gas components in the flow of gases, which were slowly passed through the thermal chamber. In order to bring the composition of the gases into proximity with the composition of flue gases in the baking furnace at production, air was supplied by compressor 9 and carbon dioxide was supplied from cylinder $\mathbf{1 0}$ to the thermal chamber. At the same time, the oxygen content in the mixture of gases was maintained at the level of 13 $15 \%, 15-16 \%$ and $17-18 \%$. Of course, the content of carbon dioxide exceeded its content in the flue gases. However, formation of carbon monoxide mainly depended on the oxygen content and its interaction with carbon materials. The composition of the gases at the outlet was monitored using gas analyzer $\mathbf{1}$. The gases (air and $\mathrm{CO}_{2}$ ) were monitored and maintained at preset level using rotameters 7. Rotameters were calibrated for gas consumption in $\mathrm{dm}^{3} / \mathrm{min}$. At this stage of the study, the temperature was raised and maintained at certain level for $7 \mathrm{~h}$. In the course of the research, the initial and final mass of carbon material was controlled.

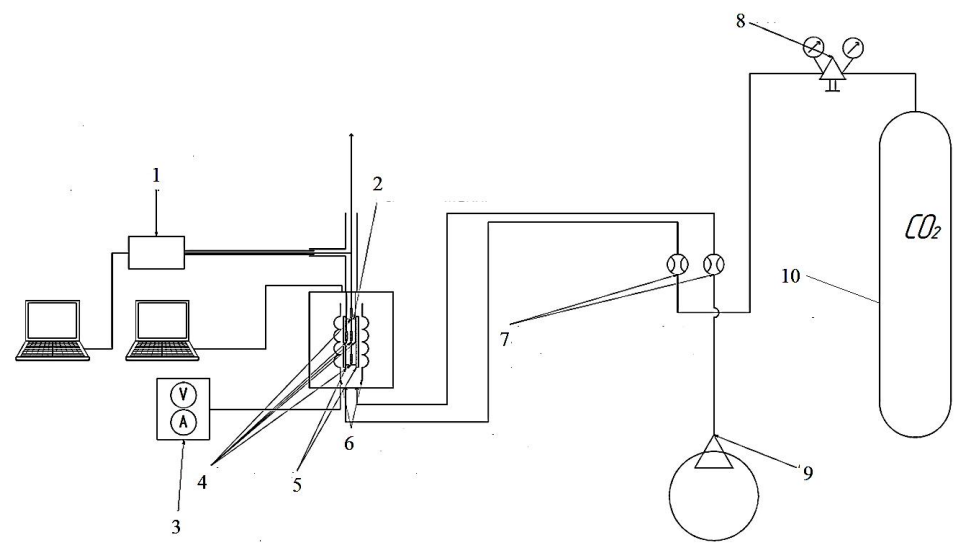

Fig. 1. Layout of the laboratory facility for simulation of gas release processes in a baking furnace: 1 - gas analyzer VARIO PLUS industrial analyzer MRU air fair; 2 - heat chamber; 3 -TENSE PC-96 temperature controller; 4 - thermocouples; 5 - ceramic wall of the thermal chamber; 6 - heating element; 7 - RF-RFM

LGFI.407142.002 EF rotameters; 8 - DONMET BKO-50 DM reducer; 9 - compressor; 10 - carbon dioxide cylinder 
To analyze the results obtained, the specific amount of carbon monoxide formed per $1 \mathrm{~g}$ of loading $(\mathrm{mg} / \mathrm{g} \cdot \mathrm{h})$ was calculated by the formula:

$$
Q_{C O}=\frac{C \cdot V}{M}
$$

where $C$ is the concentration of $\mathrm{CO}, \mathrm{mg} / \mathrm{m}^{3} ; V$ is a gas mixture flow rate, $\mathrm{m}^{3} / \mathrm{h} ; M$ is a weight of loaded carbon material, g.

\section{Results and Discussion}

When determining the influence of temperature, concentration of oxygen in the gas phase and the packing materials as a kind of carbon material on the composition of gas emissions, about $445 \mathrm{~g}$ of the packing materials were loaded in the thermal chamber of the laboratory facility and the gas mixture was passed through it with a flow rate of $131.4 \mathrm{dm}^{3} / \mathrm{h}$ at oxygen concentration of 13$15 \%$; with flow rate of $98.4 \mathrm{dm}^{3} / \mathrm{h}$ at oxygen concentration of $15-16 \%$ and with flow rate of $60 \mathrm{dm}^{3} / \mathrm{h}$ at oxygen concentration of $17-18 \%$. The changes in the concentration of carbon monoxide in the gas mixture, which passed through the heat chamber are represented in Fig. 2.

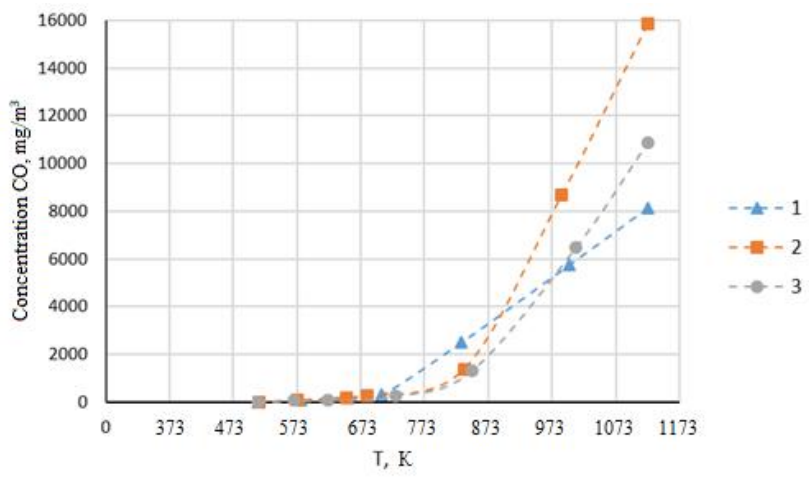

Fig. 2. Changes in $\mathrm{CO}$ concentration with rising temperature in gas mixture passed through thermal chamber loaded with packing materials $(M=431.4-445 \mathrm{~g})$ at the gas consumption of $131.4 \mathrm{dm}^{3} / \mathrm{h}(1)\left(C_{\mathrm{O} 2}=13-15 \%\right) ; 98.4 \mathrm{dm}^{3} / \mathrm{h}(2)$ $\left(C_{\mathrm{O} 2}=15-16 \%\right)$ and $60.0 \mathrm{dm}^{3} / \mathrm{h}(3)\left(C_{\mathrm{O} 2}=17-18 \%\right)$

In this case, it should be noted that in the temperature range of 373-673 K, the CO concentration in the gas mixture was insignificant and only at temperatures of $523-673 \mathrm{~K}$ it gradually increased to $125-250 \mathrm{mg} / \mathrm{m}^{3}$ regardless of oxygen concentration in the gas mixture. Further, up to temperature of $926 \mathrm{~K}, \mathrm{CO}$ concentration grew faster at oxygen concentration of $13-15 \%$, and at higher temperatures - at oxygen concentration of 15 $16 \%$. The maximum concentration of $\mathrm{CO}$ reached $13025-18625 \mathrm{mg} / \mathrm{m}^{3}$ at oxygen concentration of $15-16 \%$.
In addition to measuring the content of carbon monoxide at heating the packing materials, the concentration of methane was monitored. As can be seen from Fig. 3, the concentration of methane increases with rising temperature. Concentrations of methane at all concentrations of oxygen used are close to each other and reach $450-650 \mathrm{mg} / \mathrm{m}^{3}$ at the maximum temperature. There is practically no hydrogen in the gas mixture at heating the packing materials. In some cases, trace amounts of hydrogen were detected.

The loss in mass of the packing materials reached 11-15 g per 431-445 $\mathrm{g}$ of the initial material and reached $3.311,2.295$ and $1.947 \%$ at oxygen concentration in the gas mixture of $13-15,15-16$ and $17-18 \%$, respectively. As can be seen from the results of the research, with the increase in the concentration of oxygen in the gas mixture, the loss in mass of the packing materials is minimal.

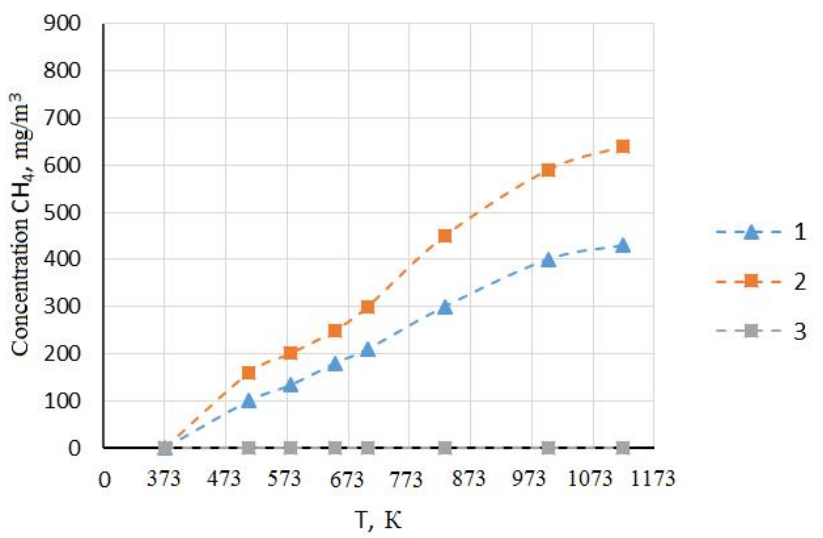

Fig. 3. Change in methane concentration with rising temperature in the gas mixture passed through thermal chamber loaded with packing materials $(M=430-455 \mathrm{~g})$ at the gas consumption of $131.4 \mathrm{dm}^{3} / \mathrm{h}$ (1) $\left(C_{\mathrm{O} 2}=13-15 \%\right) ; 98.4 \mathrm{dm}^{3} / \mathrm{h}(2)$ $\left(C_{\mathrm{O} 2}=15-16 \%\right)$ and $60.0 \mathrm{dm}^{3} / \mathrm{h}(3)\left(C_{\mathrm{O} 2}=17-18 \%\right)$

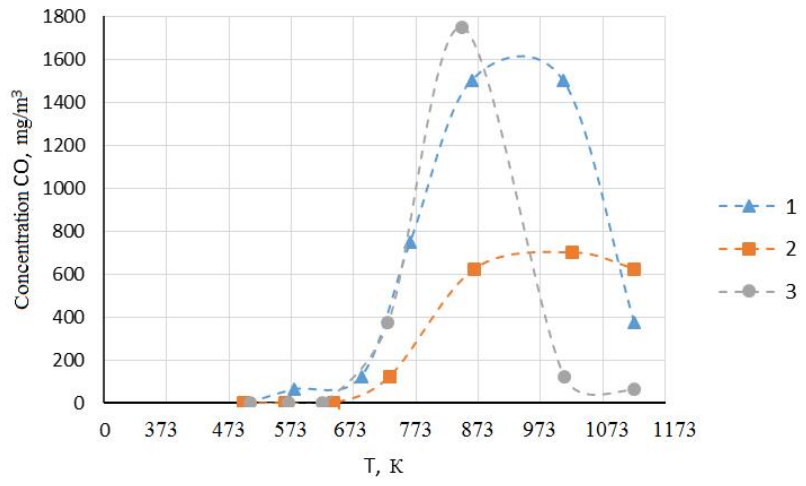

Fig. 4. Dependence of the carbon monoxide concentration on the temperature in the gas mixture after passing through the thermal chamber loaded with the granular pitch $(M=5 \mathrm{~g})$ at the gas consumption ща $131.4 \mathrm{dm}^{3} / \mathrm{h}$ (1) $\left(C_{\mathrm{O} 2}=13-15 \%\right) ; 98.4 \mathrm{dm}^{3} / \mathrm{h}(2)$ $\left(C_{\mathrm{O} 2}=15-16 \%\right)$ and $60.0 \mathrm{dm}^{3} / \mathrm{h}(3)\left(C_{\mathrm{O} 2}=17-18 \%\right)$ 
A slightly different picture was observed at heating $5 \mathrm{~g}$ sample weight of pitch, which is used for production of electrode mass, in heat chamber, at passing gas mixture with the consumption of 131.4, 98.4 and $60.0 \mathrm{dm}^{3} / \mathrm{h}$ at oxygen concentrations of $13-15,15-16$ and $17-18 \%$, respectively (Fig. 4).

It is obvious that in this case, in addition to the concentration of oxygen, oxidation of the pitch is affected by the quantity of oxygen passed, which significantly decreases from the first to the third case. In this case, a significant release of carbon monoxide is observed already at $614 \mathrm{~K}$ at the maximum consumption of the gas mixture. At the minimum consumption of the gas mixture, the release of carbon monoxide began at $689 \mathrm{~K}$, and at the gas consumption of $98.4 \mathrm{dm}^{3} / \mathrm{h}$, the gas release began at $739 \mathrm{~K}$. But, with the temperature rising above 914-989 K, the $\mathrm{CO}$ concentration in the gas mixture decreases.

Sufficiently high concentrations of methane were achieved when the pitch was heated in the thermal chamber. Its main mass released at temperatures of $652-$ 938 K (Fig. 5). Hydrogen release was not observed.

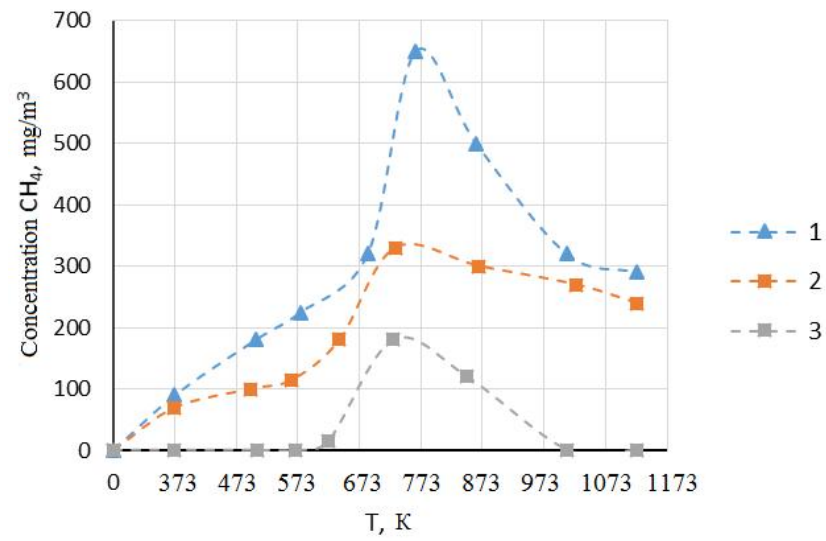

Fig. 5. Dependence of methane concentration on the temperature in the gas mixture after passing through the thermal chamber loaded with the granular pitch $(M=5 \mathrm{~g})$ at the gas consumption of $131.4 \mathrm{dm}^{3} / \mathrm{h}(1)\left(C_{\mathrm{O} 2}=13-15 \%\right) ; 98.4 \mathrm{dm}^{3} / \mathrm{h}(2)$ $\left(C_{\mathrm{O} 2}=15-16 \%\right)$ and $60.0 \mathrm{dm}^{3} / \mathrm{h}(3)\left(C_{\mathrm{O} 2}=17-18 \%\right)$

The next stage of the research was to determine the dependence of the composition of gas emissions on the temperature and oxygen content when using the charge mixture as a carbon material for manufacturing the electrodes with a gas mixture consumption of 135.2, 131.4 and $98.4 \mathrm{dm}^{3} / \mathrm{h}$ at oxygen concentrations of $13-15,15-16$ and $17-18 \%$, respectively. The sample weight of the charge mixture in this case was $450 \mathrm{~g}$. As a result of the research it was found that a significant formation of carbon monoxide was observed at the temperatures above 693-723 K and up to 873-953 K (Fig. 6).
With regard to the formation of methane, as in the case of using the packing materials as a loading, the concentration of methane increases with the heating temperature of the charge mixture and changes at the maximum temperature in the range of $500-680 \mathrm{mg} / \mathrm{m}^{3}$ (Fig. 7).

Hydrogen in the gas mixture releases in small amounts when the charge mixture is heated to the temperatures of 873-973 K. Its concentration varies in the range of $4-67 \mathrm{mg} / \mathrm{m}^{3}$.

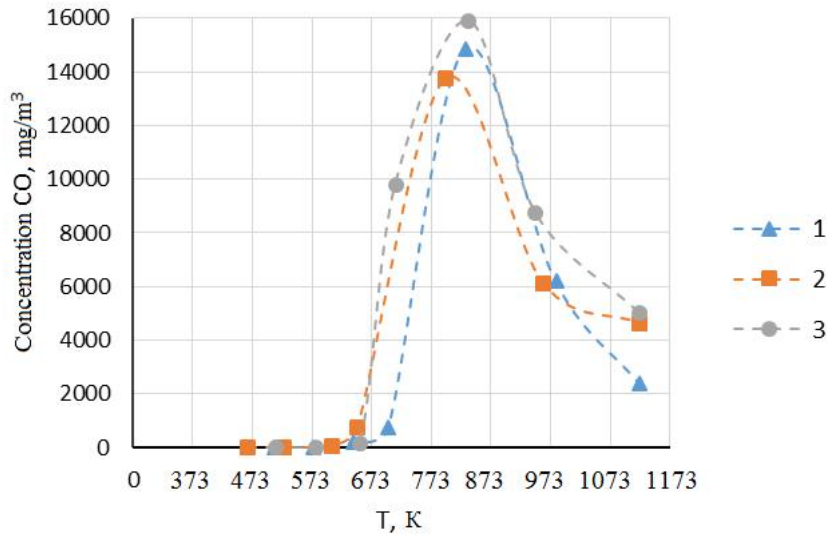

Fig. 6. Change in the carbon monoxide concentration with rising temperature after passing through the thermal chamber loaded with the charge mixture $(M=450 \mathrm{~g})$ at the gas consumption of $135.2 \mathrm{dm}^{3} / \mathrm{h}(1)\left(C_{\mathrm{O} 2}=13-15 \%\right) ; 131.4 \mathrm{dm}^{3} / \mathrm{h}(2)$

$\left(C_{\mathrm{O} 2}=15-16 \%\right)$ and $98.4 \mathrm{dm}^{3} / \mathrm{h}(3)\left(C_{\mathrm{O} 2}=17-18 \%\right)$

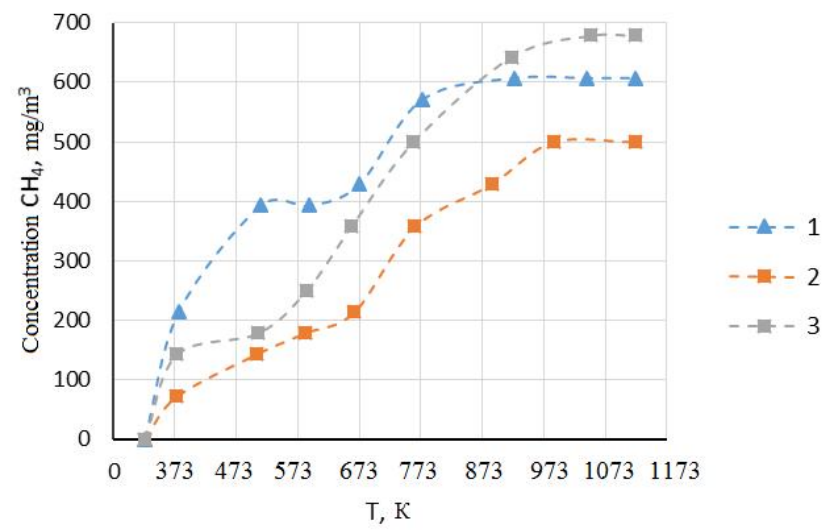

Fig. 7. Change in methane concentration with rising temperature after passing through the thermal chamber loaded with the charge mixture $(m=450 \mathrm{~g})$ at the gas consumption of $135.2 \mathrm{dm}^{3} / \mathrm{h}(1)\left(C_{\mathrm{O} 2}=13-15 \%\right) ; 131.4 \mathrm{dm}^{3} / \mathrm{h}(2)$

$\left(C_{\mathrm{O} 2}=15-16 \%\right)$ and $98.4 \mathrm{dm}^{3} / \mathrm{h}(3)\left(C_{\mathrm{O} 2}=17-18 \%\right)$

It is known that carbon monoxide, along with carbon dioxide, is formed by the interaction of solid carbon with oxygen [2]:

$$
\begin{array}{r}
3 \mathrm{C}+2 \mathrm{O}_{2}=\mathrm{C}_{3} \mathrm{O}_{4} \\
\mathrm{C}_{3} \mathrm{O}_{4}=2 \mathrm{CO}+\mathrm{CO}_{2}
\end{array}
$$


Reaction of decomposition of the complex $\mathrm{C}_{3} \mathrm{O}_{4}$ in the presence of oxygen follows the scheme:

$$
\mathrm{C}_{3} \mathrm{O}_{4}+\mathrm{O}_{2}=2 \mathrm{CO}+2 \mathrm{CO}_{2}
$$

Formation of carbon monoxide due to the interaction of methane with oxygen or water vapour is also possible:

$$
\begin{gathered}
\mathrm{CH}_{4}+1 / 2 \mathrm{O}_{2} \rightarrow \mathrm{CO}+2 \mathrm{H}_{2}+35.6 \mathrm{~kJ} \\
\mathrm{CH}_{4}+\mathrm{H}_{2} \mathrm{O} \rightarrow \mathrm{CO}+3 \mathrm{H}_{2}
\end{gathered}
$$

And oxidation of graphite with oxygen is possible, too:

$$
\mathrm{C}+1 / 2 \mathrm{O} 2=\mathrm{CO}+110.5 \mathrm{~kJ}
$$

Here, at high temperatures in the presence of oxygen, carbon monoxide can be oxidized up to carbon dioxide:

$$
\mathrm{CO}+\mathrm{O}_{2} \leftrightarrow \mathrm{CO}_{2}+283 \mathrm{~kJ}
$$

The reaction takes place in the presence of water vapour traces. In this case, transformation of $\mathrm{CO}$ into $\mathrm{CO}_{2}$ passes mainly through the following intermediate reactions:

$$
\begin{aligned}
& \mathrm{H}^{\prime}+\mathrm{O}_{2}=\mathrm{O}^{\prime} \mathrm{H}+\mathrm{O}^{\prime} \\
& \mathrm{O}^{\prime} \mathrm{H}+\mathrm{CO}=\mathrm{CO}_{2}+\mathrm{H}^{\prime}
\end{aligned}
$$

It should be noted that in the temperature range of $573-873 \mathrm{~K}$ the reaction rate constant (Eq. (10)) is quite significant and varies little in the range of (1.51$2.57) \cdot 10^{12} \mathrm{~cm}^{3} / \mathrm{mol} \cdot \mathrm{s}$. Whereas the rate-limiting step of formation of $\mathrm{O}^{\prime} \mathrm{H}$ radicals in the reaction (9) depends to a large extent on the temperature, and the reaction rate constant increases in the same temperature range from $7.28 \cdot 10^{-1} \mathrm{~cm}^{3} / \mathrm{mol} \cdot \mathrm{s}$ to $6.89 \cdot 10^{4} \mathrm{~cm}^{3} / \mathrm{mol} \cdot \mathrm{s}$, that is, almost 5 orders of magnitude. Obviously, the entire process of oxidation of carbon monoxide significantly accelerates with rising temperature.
Thus, concentration of $\mathrm{CO}$ in the gas mixture in all cases is the result of a dynamic equilibrium between Eqs. (2)-(4) and, possibly, Eqs. (5)-(7), which leads to the formation of carbon monoxide, and Eq. (8), which goes according to the scheme: Eq. (9) - Eq. (10), and provides oxidation of carbon monoxide up to carbon dioxide.

Summarizing the results of the experimental studies, we can say that the temperature range, in which $\mathrm{CO}$ forms during baking the carbon materials, is significantly different from the previously published data. It was believed that the bulk of carbon monoxide is formed at temperatures of 593$663 \mathrm{~K}$. And this was the main reason that prevented the creation of conditions for the oxidation of $\mathrm{CO}$ in the technological process. From the data obtained, it is evident that the carbon monoxide is actually formed at temperatures higher than $673 \mathrm{~K}$, which makes it possible to oxidize $\mathrm{CO}$ in the presence of catalysts up to $\mathrm{CO}_{2}$ and significantly reduce carbon monoxide emissions. If we compare the contribution of the components of the electrodes and the packing materials in the formation of $\mathrm{CO}$, then it is quite difficult to evaluate these processes only according to the graphs (Figs. 2-7).

The fact is that supply of the gases to the heat chamber was adjusted to achieve a given concentration of oxygen and the consumption of the gases was different at different oxygen concentrations. In this case, the amount of formed $\mathrm{CO}$ is determined not only by its concentration in the gas mixture, but is calculated as the gas consumption for the concentration during the degassing period. Therefore, practical interest is the calculation of the value of the amount of generated gas for a certain

\begin{tabular}{|c|c|c|c|c|c|c|c|c|c|c|c|c|}
\hline \multirow[b]{2}{*}{$t, \mathrm{~h}$} & \multicolumn{3}{|c|}{$T_{a v}, \mathrm{~K}$} & \multicolumn{3}{|c|}{$\left[\mathrm{CO}_{a v}\right], \mathrm{mg} / \mathrm{m}^{3}$} & \multicolumn{3}{|c|}{$M, \mathrm{~g}(\Delta M, \%)$} & \multicolumn{3}{|c|}{$Q_{\mathrm{co}}, \mathrm{mg} / \mathrm{g} \cdot \mathrm{h}$} \\
\hline & $\begin{array}{c}\mathrm{I} \\
(13- \\
15 \% \\
\left.\mathrm{O}_{2}\right)\end{array}$ & $\begin{array}{c}\text { II } \\
(15- \\
16 \% \\
\left.\mathrm{O}_{2}\right)\end{array}$ & $\begin{array}{c}\text { III } \\
(17- \\
18 \% \\
\left.\mathrm{O}_{2}\right)\end{array}$ & $\begin{array}{c}\mathrm{I} \\
(13- \\
15 \% \\
\left.\mathrm{O}_{2}\right)\end{array}$ & $\begin{array}{c}\text { II } \\
(15-16 \\
\left.\% \mathrm{O}_{2}\right)\end{array}$ & $\begin{array}{c}\text { III } \\
(17-18 \\
\left.\% \mathrm{O}_{2}\right)\end{array}$ & $\begin{array}{c}\mathrm{I} \\
(13-15 \\
\left.\% \mathrm{O}_{2}\right)\end{array}$ & $\begin{array}{c}\text { II } \\
(15-16 \\
\left.\% \mathrm{O}_{2}\right)\end{array}$ & $\begin{array}{c}\text { III } \\
(17-18 \\
\left.\% \mathrm{O}_{2}\right)\end{array}$ & $\begin{array}{c}\mathrm{I} \\
(13-15 \\
\left.\% \mathrm{O}_{2}\right)\end{array}$ & $\begin{array}{c}\text { II } \\
(15-16 \\
\left.\% \mathrm{O}_{2}\right)\end{array}$ & $\begin{array}{c}\text { III } \\
(17-18 \\
\left.\% \mathrm{O}_{2}\right)\end{array}$ \\
\hline 1 & 511 & 513 & 512 & 0 & 0 & 0 & 445.0 & 431.4 & 431.4 & 0.0 & 0.0 & 0.0 \\
\hline 2 & 578 & 574 & 569 & 63 & 63 & 63 & - & - & - & 0.0186 & 0.0139 & 0.0087 \\
\hline 3 & 652 & 650 & 622 & 188 & 188 & 63 & - & - & - & 0.0553 & 0.0417 & 0.0087 \\
\hline 4 & 705 & 683 & 728 & 313 & 250 & 250 & - & - & - & 0.2480 & 0.0580 & 0.0377 \\
\hline 5 & 831 & 835 & 847 & 2813 & 1375 & 1313 & - & - & - & 1.2290 & 0.3130 & 0.1855 \\
\hline 6 & 1000 & 988 & 1011 & 4250 & 8688 & 6500 & - & - & - & 1.2539 & 1.9796 & 0.9040 \\
\hline 7 & 1123 & 1123 & 1123 & 8125 & 15875 & 10875 & $\begin{array}{c}430 \\
(3.371) \\
\end{array}$ & $\begin{array}{c}421.5 \\
(2.295) \\
\end{array}$ & $\begin{array}{c}423 \\
(1.947) \\
\end{array}$ & 2.4000 & 3.6207 & 1.5126 \\
\hline & & & & & & & & & $Q_{\mathrm{CO}}^{a v}$ & 0.7488 & 0.8610 & 0.3796 \\
\hline
\end{tabular}
time, reduced to a mass unit of carbon material. Just this index is calculated by Eq. (1) and is shown in Tables 2-4.

Table 2

Dependence of the carbon monoxide amount formed from $1 \mathrm{~g}$ of the packing materials on the packing materials mass and temperature at the gas mixture consumption of 131.4 (I), 98.4 (II) and 60.0 (III) $\mathrm{dm}^{3} / \mathrm{h}$ 
Thus, when using the packing materials as a carbon material at temperatures up to $673 \mathrm{~K}$, the specific amount of carbon monoxide produced per $1 \mathrm{~g}$ of the loading reaches $0.0553 \mathrm{mg} / \mathrm{g} \cdot \mathrm{h}$ for the gas mixture containing $13-$ $15 \%$ of oxygen, $0.0417 \mathrm{mg} / \mathrm{g} \cdot \mathrm{h}$ at oxygen concentration of $15-16 \%$ and only $0.0087 \mathrm{mg} / \mathrm{g} \cdot \mathrm{h}$ at oxygen concentration of $17-18 \%$. In all cases, the index increases with rising temperature and at $923-1073 \mathrm{~K}$ it increases to $1.2539,1.9796$ and $0.9040 \mathrm{mg} / \mathrm{g} \cdot \mathrm{h}$ with increasing oxygen content in the gas mixture from $13-15 \%$ to $17-18 \%$; and at a temperature of $1123 \mathrm{~K}$ this indicator is respectively $2.400,3.6207$ and $1.5126 \mathrm{mg} / \mathrm{g} \cdot \mathrm{h}$. It is obvious that with the increase in the oxygen concentration up to $15-16 \%$, the amount of the formed $\mathrm{CO}$ increases with rising temperature. In general, for the whole time of heating, the average index of the amount of $\mathrm{CO}$ formed is the highest for oxygen concentrations of $15-16 \%$ and reaches $Q_{\mathrm{CO}}{ }^{a v}=0.8610 \mathrm{mg} / \mathrm{g} \cdot \mathrm{h}$. It is interesting to note that the specific amount of carbon monoxide formed per $1 \mathrm{~g}$ of carbon load, calculated for the baking furnace at the production, for the entire production cycle of the blanks processing amounts to $0.12297 \mathrm{mg} / \mathrm{g} \cdot \mathrm{h}$. Perhaps this is due to the fact that flue gases contain up to $8 \%$ of water vapour, which accelerates the reaction of $\mathrm{CO}$ oxidation in the reactions given in the literature [9], which generally ensures a reduction in its concentration in the gas mixture.

In this case, the bulk of $\mathrm{CO}$ releases in the temperature range of $773-1123 \mathrm{~K}$ with the increase in the amount of the formed carbon monoxide with rising temperature.

Increasing the concentration of methane with rising temperature can be associated with the presence of a certain amount of hydrocarbons in the mass of the packing materials, which are released with rising temperature. It is difficult to explain the formation of methane by pyrolysis at temperatures from 373 to $1123 \mathrm{~K}$.

Table 3

Dependence of the carbon monoxide amount formed from $1 \mathrm{~g}$ of the heated granular pitch on the temperature and heating time at the gas mixture consumption of 131.4 (I), 98.4 (II) and 60.0 (III) $\mathrm{dm}^{3} / \mathrm{h}$

\begin{tabular}{|c|c|c|c|c|c|c|c|c|c|c|c|c|}
\hline \multirow[b]{2}{*}{$t, \mathrm{~h}$} & \multicolumn{3}{|c|}{$T_{a v}, \mathrm{~K}$} & \multicolumn{3}{|c|}{$\left[\mathrm{CO}_{a v}\right], \mathrm{mg} / \mathrm{m}^{3}$} & \multicolumn{3}{|c|}{$M, \mathrm{~g}(\Delta M, \%)$} & \multicolumn{3}{|c|}{$Q_{\mathrm{CO}}, \mathrm{mg} / \mathrm{g} \cdot \mathrm{h}$} \\
\hline & $\begin{array}{c}\mathrm{I} \\
(13-15 \\
\left.\% \mathrm{O}_{2}\right)\end{array}$ & $\begin{array}{c}\text { II } \\
(15-16 \\
\left.\% \mathrm{O}_{2}\right)\end{array}$ & $\begin{array}{c}\text { III } \\
(17-18 \\
\left.\% \mathrm{O}_{2}\right)\end{array}$ & $\begin{array}{c}\mathrm{I} \\
(13-15 \\
\left.\% \mathrm{O}_{2}\right)\end{array}$ & $\begin{array}{c}\mathrm{II} \\
(15-16 \\
\left.\% \mathrm{O}_{2}\right)\end{array}$ & $\begin{array}{c}\text { III } \\
(17-18 \\
\left.\% \mathrm{O}_{2}\right)\end{array}$ & $\begin{array}{c}\mathrm{I} \\
(13-15 \\
\left.\% \mathrm{O}_{2}\right)\end{array}$ & $\begin{array}{c}\text { II } \\
(15-16 \\
\left.\% \mathrm{O}_{2}\right)\end{array}$ & $\begin{array}{c}\text { III } \\
(17-18 \\
\left.\% \mathrm{O}_{2}\right)\end{array}$ & $\begin{array}{c}\mathrm{I} \\
(13-15 \\
\left.\% \mathrm{O}_{2}\right)\end{array}$ & $\begin{array}{c}\text { II } \\
(15-16 \% \\
\left.\mathrm{O}_{2}\right)\end{array}$ & $\begin{array}{c}\text { III } \\
(17-18 \% \\
\left.\mathrm{O}_{2}\right)\end{array}$ \\
\hline 1 & 504 & 496 & 507 & 0 & 0 & 0 & 5.0 & 5.0 & 5.0 & 0.0 & 0.0 & 0.0 \\
\hline 2 & 577 & 563 & 569 & 63 & 0 & 0 & $\begin{array}{lll}- & \\
\end{array}$ & - & - & 1.6425 & 0.0 & 0.0 \\
\hline 3 & 686 & 640 & 622 & 63 & 0 & 0 & - & - & - & 1.6425 & 0.0 & 0.0 \\
\hline 4 & 764 & 731 & 728 & 438 & 63 & 250 & - & - & - & 11.4975 & 1.6425 & 6.5700 \\
\hline 5 & 862 & 867 & 847 & 1125 & 375 & 970 & - & - & - & 29.5650 & 9.3550 & 25.4900 \\
\hline 6 & 1009 & 1024 & 1011 & 938 & 1163 & 438 & - & - & - & 24.6375 & 17.4105 & 11.4900 \\
\hline 7 & 1123 & 1123 & 1123 & 375 & 375 & 63 & $\begin{array}{c}2.2 \\
(56)\end{array}$ & $\begin{array}{c}2.5 \\
(50) \\
\end{array}$ & $\begin{array}{c}2.5 \\
(50)\end{array}$ & 8.8550 & 9.855 & 1.6425 \\
\hline & & & & & & & & & $Q_{\mathrm{CO}}^{a v}$ & 11.120 & 4.2705 & 6.4561 \\
\hline
\end{tabular}

Table 4

Dependence of the carbon monoxide amount formed from $1 \mathrm{~g}$ of the heated charge mixture on the temperature and heating time at the gas mixture consumption of 131.4 (I), 98.4 (II) and 60.0 (III) $\mathrm{dm}^{3} / \mathrm{h}$

\begin{tabular}{|c|c|c|c|c|c|c|c|c|c|c|c|c|}
\hline \multirow{3}{*}{$t, \mathrm{~h}$} & \multicolumn{3}{|c|}{$T_{a v}, \mathrm{~K}$} & \multicolumn{3}{|c|}{$\left[\mathrm{CO}_{a v}\right], \mathrm{mg} / \mathrm{m}^{3}$} & \multicolumn{3}{|c|}{$M, \mathrm{~g}(\Delta M, \%)$} & \multicolumn{3}{|c|}{$Q_{\mathrm{co}}, \mathrm{mg} / \mathrm{g} \cdot \mathrm{h}$} \\
\hline & I & II & III & $\begin{array}{c}\text { I } \\
\end{array}$ & II & III & I & II & III & I & II & III \\
\hline & $\left.\% \mathrm{O}_{2}\right)$ & $\% \mathrm{O}_{2}$ ) & $\begin{array}{l}(17-18 \\
\left.\% \mathrm{O}_{2}\right)\end{array}$ & $\left.\% \mathrm{O}_{2}\right)$ & $\left.\% \mathrm{O}_{2}\right)$ & $\begin{array}{l}(1 /-18 \\
\left.\% \mathrm{O}_{2}\right)\end{array}$ & $\begin{array}{l}(13-15 \\
\left.\% \mathrm{O}_{2}\right)\end{array}$ & $\begin{array}{l}(1)-16 \\
\left.\% \mathrm{O}_{2}\right)\end{array}$ & $\begin{array}{l}(1 /-18 \\
\left.\% \mathrm{O}_{2}\right)\end{array}$ & $\begin{array}{l}(13-15 \\
\left.\% \mathrm{O}_{2}\right)\end{array}$ & $\left.\% \mathrm{O}_{2}\right)$ & $\left.\% \mathrm{O}_{2}\right)$ \\
\hline 1 & 510 & 465 & 513 & 0 & 0 & 0 & 450 & 450 & 450 & 0.0 & 0.0 & 0.0 \\
\hline 2 & 575 & 525 & 580 & 0 & 0 & 0 & - & - & - & 0.0 & 0.0 & 0.0 \\
\hline 3 & 643 & 606 & 653 & 188 & 63 & 125 & - & - & - & 0.0563 & 0.0188 & 0.0376 \\
\hline 4 & 701 & 649 & 713 & 438 & 438 & 5025 & - & - & - & 0.1314 & 0.1314 & 1.5097 \\
\hline 5 & 830 & 797 & 836 & 7625 & 7250 & 12850 & - & - & - & 2.2908 & 2.1170 & 3.8607 \\
\hline 6 & 982 & 961 & 948 & 6188 & 6125 & 8750 & - & - & - & 1.8600 & 1.8402 & 2.6289 \\
\hline 7 & 1123 & 1123 & 1123 & 2375 & 4625 & 5000 & $\begin{array}{c}409 \\
(9.1)\end{array}$ & $\begin{array}{c}411 \\
(8.67)\end{array}$ & $405(10)$ & 0.7139 & 1.3895 & 1.5022 \\
\hline & & & & & & & & & $Q_{\mathrm{CO}}{ }^{a v}$ & 0.7217 & 0.7852 & 1.3627 \\
\hline
\end{tabular}


Reducing the mass of the packing materials with increasing oxygen concentration can be associated with a decrease in the consumption of the gas-air mixture, which in general led to a decrease in the amount of the oxygen passed. Thus, at oxygen concentration of $13-15 \%$, the gas consumption was $131.4 \mathrm{dm}^{3} / \mathrm{h}$, or $919.8 \mathrm{dm}^{3}$ for $7 \mathrm{~h}$, where $14 \%$ or $128.772 \mathrm{dm}^{3}$ is oxygen. At oxygen concentration of $15-16 \%$, the gas mixture consumption was $98.4 \mathrm{dm}^{3} / \mathrm{h}$, or totally $688.8 \mathrm{dm}^{3}$, including $106.76 \mathrm{dm}^{3}$ of oxygen. At the consumption of the gas mixture of $60 \mathrm{dm}^{3} / \mathrm{h}$, the amount of the oxygen passed is only $73.5 \mathrm{dm}^{3}$. Just this explains the reduction in the amount of carbon monoxide formed at reducing the consumption of the gas mixture.

As for the pitch, the choice of its mass was determined by the experimental conditions, its melting temperature and high content of resinous substances [10], which prevented the normal operation of the gas analyzer. In the course of the studies with the pitch, a sharp increase in the concentration of $\mathrm{CO}$ at the temperature of $614 \mathrm{~K}$ at the maximum consumption of the gas mixture can be explained by the content in this load of resinous substances that begin to oxidize first. Further decrease in the concentration of $\mathrm{CO}$ at the temperatures above 914$989 \mathrm{~K}$ is associated both with a higher rate of oxidation of organic substances of the pitch and with a small weight of the used pitch sample (only $5 \mathrm{~g}$ ), which is almost 100 times less than the heated packing materials. Therefore, the reduction of $\mathrm{CO}$ concentration when heating above the temperature of $914 \mathrm{~K}$ in the gas mixture can be argued by the exhaustion of the bulk of volatile substances of the pitch. After all, the weight loss of the pitch (Table 3 ) in this case was 56.0, 50.0 and $50.0 \%$ at the gas consumption of 131.4, 98.4 and $60.0 \mathrm{dm}^{3} / \mathrm{h}$, respectively.

Undoubtedly, the pitch contains volatile substances that are easily oxidized with the formation of carbon monoxide. As can be seen from Table 3, at different gas consumptions, the specific rate of oxidation of organic substances in terms of $1 \mathrm{~g}$ of organic mass per hour reaches $17.4105,25.490$ and even $29.5650 \mathrm{mg}$. This is an order of magnitude more than in the case of the packing materials. In general, the amount of the formed carbon monoxide directly depends on the amount of oxygen supplied, which in this case depends more on the gas consumption than on the oxygen concentration.

High concentrations of $\mathrm{CO}$ formed in the studies with the charge mixture can undoubtedly be justified by the fact that the crushed charge mixture has a developed surface, which specific area of contact with air is significant. The proof of this fact is a decrease of the charge mixture mass by $9 \%$. However, taking into account that $Q_{\mathrm{CO}}$ value reached $0.113140-3.8607 \mathrm{mg} / \mathrm{g} \cdot \mathrm{h}$ (Table 4), it can be concluded that the specific amount of carbon monoxide from the charge mixture prevails that from the packing materials, but is inferior to the pitch.

Since the experimental temperature was lower than the pyrolysis temperature, and there was nearly no water vapour in the gas mixture, then there was some reason to wait for a high concentration of methane, which was confirmed experimentally.

Taking into account the given results, which show that carbon monoxide is formed at sufficiently high temperatures, it is quite promising to use water vapour and other catalysts to significantly reduce its amount.

\section{Conclusions}

Thermal oxidation processes of carbon components (packing materials, pitch, charge mixture) were studied at passing the gas mixture with oxygen concentration of $13-$ $15,15-16$ and $17-18 \%$ within the temperature range up to $1123 \mathrm{~K}$. It has been shown that when heating the packing materials, the bulk of carbon monoxide is formed at $773-1123 \mathrm{~K}$, when heating the pitch - at the temperatures of $614-989 \mathrm{~K}$, when heating the charge mixture - at $693-953 \mathrm{~K}$. 2. It has been determined that due to the presence of large amount of volatile substances, the pitch allows the highest rate of carbon oxidation with the release of $\mathrm{CO}$ and significantly exceeds this index for the packing materials and the charge mixture. The specific amount of carbon monoxide formed per gram of carbon load per hour in the range up to $1123 \mathrm{~K}$ has been calculated. It is established that this index depends on the type of carbon material, gas mixture consumption, oxygen concentration and temperature regime.

\section{References}

[1] Kutuzov S., Buriak V., Churilin V. et al.: IV Int. Congress "Non-Ferrous Metals". Russia, Krasnoyarsk 2012, 943.

[2] Panov Ye., Shylovych I., Ivanenko E. et al.: East.-Eur. J. Enterpr. Technol., 2012, 58, 15.

[3] Karvatskyi A., Leleka S., Pulinets I. et al.: East.-Eur. J. Enterpr. Technol., 2011, 54, 42.

[4] Karvatskyi A., Shylovych I., Krutous L. et al.: East.-Eur. J. Enterpr. Technol, 2013, 62, 38.

[5] Bogacki M., Oleniacz R., Mazur M. et al.: Environ. Protect. Eng., 2012, 38, 15. 
[6] Rattan G., Kumar M.: Chem. Chem. Technol., 2014, 8, 249. https://doi.org/10.23939/chcht08.03.249

[7] Kostrobii P., Ryzha I.: Chem. Chem. Technol., 2018, 12, 451. https://doi.org/10.23939/chcht12.04.451

[8] Gomelya N., Ivanenko E.: The IX International Youth Science Environmental Forum "Ecobaltica-2012". Russia, St-Petersburg 2012, 89.

[9] Fokin V., Malakhov A., Malakhov S. et al.: Tsvetnye Metally, 2002, 4, 48 .

[10] Mazur M., Oleniacz R., Bogacki M. et al:: Emission of polycyclic aromatic hydrocarbons (PAHs) during the production of carbon and graphite electrodes [in:] Pawłowski L., Dudzińska M., Pawłowski A. (Eds.), The $3^{\text {rd }}$ Congress of Environmental Engineering, v.3. CRC Press/Balkema, Taylor \& Francis Group, Leiden-London 2010, 59-66.

Received: March 13, 2019 / Revised: June 25, 2019 / Accepted: November 15, 2019

\section{ВИЗНАЧЕННЯ УМОВ ОКИСНЕННЯ КАРБОНОВИХ МАТЕРІАЛІВ 3 УТВОРЕННЯМ ОКСИДУ КАРБОНУ ЗА ВИСОКИХ ТЕМПЕРАТУР}

Анотація. Експериментальним иляхом досліджено вплив типу карбонового матеріалу, температури та кониентрачії оксигену в газовій суміші на процеси утворення оксиду карбону при виробництві електродів шияхом графітаиії в печах обпалу. Розраховано питому кількість утвореного газу за певний час, приведений до одиничі маси карбонового завантаження на прикладі пересипки, пеку та шихти промислового застосування. Показано, щуо пек забезпечує найвищу швидкість окиснення карбону з виділенням СО $i$ суттєво за иим показником переважає пересипку і шихту.

Ключові слова: оксид карбону, газовиділення, пересипка, пек, иихта. 